\title{
Persepsi Guru dan Siswa Jurusan Akuntansi di SMKN 1 Negara Tentang Penghapusan Ujian Nasional
}

\author{
I Gede Palguna Yasa*1, Luh Indrayani² \\ 1,2 Program Studi Pendidikan Ekonomi \\ Universitas Pendidikan Ganesha \\ Singajara, Indonesia
}

e-mail: igedepalgunayasa20@undiksha.ac.id ${ }^{* 1}$, luh indrayani@undiksha.ac.id

Pengutipan: Yasa, I.G.P. \& Indrayani ,L. (2021). Persepsi Guru dan Siswa Jurusan

Akuntansi di Smkn 1 Negara

Tentang

Penghapusan

Ujian Nasional.

Jurnal Pendidikan

Ekonomi

Undiksha, 13(2),

285-292

http://dx.doi.org/1 $\underline{0.23887 / j j p e . v 13 i}$ 2.33648

\begin{abstract}
Abstrak
Riwayat Artikel Tanggal diajukan: 9 April 2021

Tanggal diterima: 23 November 2021

Tanggal dipublikasikan: 15 Desember 2021

Tujuan dari penelitian ini yaitu untuk mengetahui persepsi guru dan siswa Jurusan Akuntansi di SMKN 1 Negara terhadap penghapusan ujian nasional. Jenis penelitian ini yaitu penelitian deskriptif untuk mendeskripsikan mengenai persepsi guru dan siswa Jurusan Akuntansi di SMKN 1 Negara terhadap penghapusan ujian nasional. Populasi dalam penelitian ini yaitu seluruh guru Jurusan Akuntansi dan siswa Jurusan Akuntansi di SMKN 1 Negara dengan sampel guru 10 dan siswa 198 dengan menggunakan rumus slovin. Metode pengumpulan data yang digunakan yaitu menggunakan kuesioner. Teknik analisis data yang digunakan dalam penelitian ini adalah analisis deskriptif. Hasil penelitian menunjukkan bahwa persepsi guru dari dimensi faktor internal skor 398 termasuk ke dalam kategori setuju. Dimensi faktor eksternal memperoleh skor 439 termasuk ke dalam kategori setuju. Persepsi siswa dari dimensi faktor internal memperoleh skor 7.814termasuk ke dalam kategori setuju. Dimensi faktor eksternal memperoleh skor 8.464 termasuk ke dalam kategori setuju. Jadi dapat disimpulkan bahwa guru dan siswa Jurusan Akuntansi di SMKN 1 Negara setuju dengan adanya penghapusan ujian nasioal.
\end{abstract}

Kata Kunci: Persepsi; Guru; Siswa; Penghapusan Ujian Nasional

\section{Abstract}

This study aimed at determining the perceptions of teachers and students of the Accounting Department at SMKN 1 Negara on the elimination of the national exam. The research design used was a descriptive study which describes teachers' and students' perception toward the elimination of national examination. This study involved all accounting teachers and students of SMK Negeri 1 Negara as a population. Meanwhile, the samples of this study were 10 accounting teachers and 198 accounting students. These samples were determined by using the Solvin formula. In collecting the data, the instrument used was a questionnaire. The obtained data were analyzed through descriptive analysis. The results of this study show that teachers' perception from the internal factor dimension obtained a score of 398 which is included in the agreed category. Further, the external factor dimension obtains a score of 439 which is also included in the agreed category. Moreover, students' perceptions of the internal factor dimension obtained a score of 7,814 which is included in the agreed category. Furthermore, the external factor dimension obtains a score of 8,464 which is included in the agreed category. From the results, it can be concluded that the teachers and students of the Accounting Department at SMKN 1 Negara agree with the elimination of the national examination.

Keywords : Perception, Teacher, Students, The Elimination of Final Examination 


\section{PENDAHULUAN}

Pendidikan merupakan suatu proses yang dilalui oleh setiap individu dalam kehidupannya. Pendidikan dapat diartikan sebagai suatu bentuk kegiatan yang membantu individu dalam mengembangkan semua poteni yang dimilikinya mulai dari pikiran, hati, rasa, dan, raga serta karsa yang dipergunakan oleh individu untuk menghadapi segala tantangan di masa depan. Dalam dunia pendidikan banyak tahap yang harus dilalui salah satunya adalah proses pembelajaran. Pembelajaran seperti yang dikemukakan oleh Sagala (2009) pembelajaran adalah keberhasilan pendidikan yang didasari dengan teori belajar dan asas pendidikan untuk mengajarkan siswa. Setelah melewati proses pembelajaran individu tersebut di uji kemampuannya dengan langkah selanjutnya yaitu tes. Tes merupakan suatu cara untuk mengetahui atau mengukur kemampuan individu dalam menyelesaikan masalah atau depat digunakan semabagi alat ukur untuk mengetahui kemampuan individu tersebut. Sependapat dengan itu Arikunto \& Jabar (2004) mengatakan alat yang digunakan mengukur atau mengetahui sesuatu dengan cara yeng telah disiapkan adalah tes. Dalam dunia pendidikan di Indonesia tes yang digunakan sebagai evaluasi akhir yang berstandar nasional dan berlaku untuk semua jenjang pendidikan adalah ujian nasional.

Di Indonesia suatu peraturan yang menjalaskan tentang ujian nasional ada pada Depdiknas (2003). Dalam pelaksanaan ujian nasioal yang diadakan dari tahun ke tahun mengalami banyak perubahan. Setelah di angkatnya mentri pendidikan yang baru yaitu Nadiem Markarin beliau membuat suatu keputusan pada tahun 2019 yang mengatakn bahwa ujian nasional yang terakhir dilaksanakan pada tahun 2020. Beliau akan mengganti sistem ujian nasional dengan hal yang baru yaitu asesmen kompetensi minimum dan survei karakter. Pelaksanaan tersebut akan di lakukan pada tahun 2021. Dalam keputusan ini beliau mengeluarkan permendikbud 43 tahun 2019 dalam peraturan ini menjelaskan bahwa akan menghapuskan tentang Peraturan Menteri Pendidikan sebelumnya yaitu peraturan mentri pendidikan dan Kebudayaan Nomor 4 Tahun 2018 dalam peraturan tersebut membahas tentang Penilaian Hasil Belajar oleh satuan pendidikan, hasil belajar dan semua itu di atur oleh pemerintah. Dari peraturan yang dikeluarkan oleh belia tersebut beliau mengajak para guru dan siswa melaksakan pembelajaran merdeka dimana guru yang mengatur semua pembelajaran yang akan dilaksanakan.

Dari keputusan tersebut banyak pihak sekolah yang mulai mempersiapkan diri untuk menghadapai hal tersebut salah satunya adalah SMKN 1 Negara. Sekolah tersebut adalah sekolah menengah kejuruan yang berlokasi di Jalan Tanjung Raya Kelurahan Baler Bale Agung, Kecamatan Negara, Kabupaten Jembrana, Provinsi Bali. SMKN 1 Negara memiliki tiga jurusan yaitu Akuntansi dan Keuangan Lembaga, Rekayasa Perangkat Lunak, dan Bisnis Daring dan Pemasaran. Dari hal tersebut maka peneliti melakukan observasi di SMKN 1 Negara mengenai pendapat sekolah tentang penghapusan ujian nasional pada tahun 2021.

Dalam melakukan observasi ke pihak sekolah peneliti melakukan wawancara kepada para guru dan siswa yang ada di SMKN 1 Negara. Pendapat para guru dan siswa di SMKN 1 Negara tentang penghapusan ujian nasional terdapat perbedaan pendapat para guru dan siswa mulai dari yang setuju dan juga yang tidak setuju. Seperti pendapat guru Guru Akuntansi Keuangan "Saya kurang setuju dengan penghapusan ujian nasional karena selain akan menghilangkan standar kelulusan secara nasional juga akan membuat peserta didik menjadi kurang dapat memiliki tanggung jawab atas dirinya baik dalam belajar maupun nantinya dalam bekerja". Pendapat guru tersebut kurang setuju tetapi ada juga guru yang setuju seperti yang dikemukakan Guru Akuntansi Perpajakan beliau mengatakan "Saya setuju dengan penghapusan ujian nasional hal ini dikarenakan nilai saat ujian nasional kurang dapat dipertanggung jawabkan. Seharusnya dari nilai rapor semester 1-5 dan catatan bimbingan konsling serta jika di SMK skill yang mereka kuasai sudah 
cukup maka sekolah menjadi penentu kelulusan saya rasa lebih baik daripada nilai ujian nasional".

Dalam melalukan observasi bukan guru saja yang berpendapat tetapi ada juga siswa yang mengeluarkan pendapat seperti yang di kemukakan oleh siswa kelas XII Jurusan Akuntansi dan Keuangan Lembaga adalah "tidak setuju, jika ujian nasional dihapus maka siswa merasa kurang semangat dalam belajar karena merasa tidak ada tantangan, terlebih lagi melanjutkan sekolah ke perguruan tinggi. Hal ini menyebabkan siswa merasa tidak ada tantangan bahkan tidak menarik bagi siswa yang membuat siswa tidak tertarik untuk mengejar perstasi bahkan membuat siswa menjadi tidak hirau dan menurunkan semangat belajar siswa".pendapat berbeda juga di kemukakan oleh siswa kelas XI Jurusan Akuntansi dan Keuangan Lembaga yang mengatakan "saya setuju dengan penghapusan ujian nasional hal ini dikarenakan akan mengurangi beban siswa yang mengakibatkan stres dan juga dapat meminimalkan biaya dalam pembelajaran yang berupa bimbel dalam upaya mempersiapkan diri dalam menghadapi ujian nasional". Perbedaan pendapat tersebut menjadi masalah dalam penghapusan ujian nasional. Dilihat dari perbedaan pendapat di atas yang di alami oleh pihak sekolah membuat peneliti tertarik untuk melakukan penelitian yang berjudul "Persepsi Guru Akuntansi dan Siswa Akuntansi di SMKN 1 Negara Tentang Penghapusan Ujian Nasional".

Dalam penelitian terdapat bebrpa kajian teori yang digunaan seperti persepsi dan ujian nasional. dalam menentukan kajian teori penelitian ini mengambil beberpa teori para ahli dan juga dari peraturan perundang-undangan. Teori yag pertama di jelaskan adalah persepsi dalam membahas persepsi banyak sekali menggunakan pendapat ahli diantarnya bimo walgita, miftha toha, dan wilcox. Teori yang pertama adalah pengerian persepsi menurut Menurut Kamus Besar Bahasal ndonesia, persepsi adalah tanggapan (penerimaan) langsung dari sesuatu, proses seseorang mengetahui beberapa hal melalui panca indranya. Selanjutnya terdapat juga teori yang dikemukakan oleh Walgito (2010) yang mengatakan bahwa persepsi merupakan suatu satu bentuk proses yang di alami oleh setiap individu dimana proses tersebut akan didahului dengan proses pengindraan selanjutnya diikuti dengan pengorganisasian san diinterpestasikan delam bentuk kesan dari individu terhadap suatu objek yang sudah mereka terima dan merupakan aktivitas integrated dalam diri individu".

Dalam persepsi terdapat juga faktorfaktor yang mempengaruhinya seperti yang dikemukanan oleh Thoha (2015) beliau mengatakan bahwa dalam persepsi terdapat dua faktor yang mempengaruhinya yaitu faktor dari dalam diri dan juga faktor dari luar diri. Faktor dari dalam diri meliputi proses belajar, kepribadian dan juga motivasi. Selain itu faktor dari luar meliputi ukuran, keberlawanan, intensitas, pengulangan dan ketidak asingan. Selain itu ada juga pendapat para ahli mengatakan faktorfaktor lain yang mempengaruhi persepsi. Seperti yang di kemukakan oleh walgito beliau mengatakan bahwa persepsi dipengaruhi oleh obyek yang dipersepsikan, indra yang dipergunakan, susunan syaraf dan pengertian, hal tersebut merupakan faktor-faktor yang mempengaruhi persepsi.

Sebelum terjadinya suatu persepsi dalam diri kita terdapat proses terbentuknya persepsi dalam proses terbentuknya persepsi ada beberapa hal yang mendasari terbentuknya persepsi di dalam diri individu seperti yang di kemukakan oleh Thoha (2015) beliau mengatakan bahwa persepsi terbentuk melalui rangsangan dan stimulus, dilanjutkan dengan registrasi, dan di akhiri dengan interpestasi. Pendapat berbeda di kemukakan oleh Gibson (dalam Simbolan (2008) mengatakan bahwa proses persepsi merupakan tahap observasi terhadap stimulus yang diterima oleh indra yang akan dimulai dari mendapatkan pengaruh realita organisasi kerja berupa sistem seperti sistem imbalan organisasi, alur kerja dan lainnya yang kemudian akan diproses menjadi persepsi individu.

Dari beberapa teori di atas yang menerangkan tentang persepsi peneliti 
menggunakan teori yang dikemukakan oleh Thoha (2015) yang mengatakan faktor-faktor yang mempengaruhi persepsi seseorang dilihat dari dalam diri dan dari luar diri. Peneliti memilih teori ini dikarenakan paling sesuai dengan masalah yang akan dicari penyelesaiannya oleh peneliti mengenai persepsi guru dan siswa terhadap penghapusan ujian nasional. Selain itu teori ini diperkuat dengan hasil penelitian yang dilakukan oleh Hartanti \& Dwihartani Muslikhah (2017) menyatakan bahwa persepsi guru dan siswa terhadap ujian nasional berbasis komputer dinilai dari faktor internal dan eksternal.

Ujian Nasional merupakan evaluasi berstandar nasional yang dilaksanakan oleh pemerintah dengan tujuan untuk menyetarakan pendidikan secara nasional. Adapun peraturan yang menjelaskan tentang ujian nasional adalah Depdiknas (2003) tentang sistem Pendidikan nasional dalam pasal 58 ayat (2). Dalam undangundang tersebut menjelaskan tentang pelaksanaan ujian nasional. ujian nasional yang ada dari tahun ketahun sangat sering mengalami perubahan. Bukan hanya perubahan di setiap tahun dalam pelaksanaan ujian nasional ada beberapa kendala dan masalah-masalah kecil yang sering di alami seperti tingkat kestresan siswa meningkat dan juga tindak kecurangan yang di lakukan oleh pihak guru maupun sekolah. Dari masalah masalah tersebut membuat pemerintah mempertimbangkan pelaksanaan ujian nasional kedepannya. Dan pada tahun 2019 sudah di putuskan bahwa ujian nasional akan dilakukan terakhir pada tahun 2020 dan di ganti dengan sisstem penilaian lain yaitu dengan asesmen kompetensi minimum dan survey karakter. Dari keputusan tersebut diikuti dengan permendikbud no 43 tahun 2019 yang mengatakan tentang pencabutan Peraturan Menteri Pendidikan dan Kebudayaan Nomor 4 Tahun 2018. Dengan dikeluarkannya keputusan tersebut maka membuat banyak pihak yang mempersiapkan diri untuk menghadapi keputusan tersebut.
Berdasarkan latar belakang dan rumusan masalah yang ada dalam penelitian ini maka peneliti mengharapkan tujuan dari penelitian ini adalah untuk mengetahui persepsi guru Jurusan Akuntansi di SMKN 1 Negara tentang penghapusan ujian nasional. Dan persepsi siswa Jurusan Akuntansi di SMKN 1 Negara tentang penghapusan ujian nasional.

\section{METODE}

Dalam penelitian ini menggunakan penelitian yang Jenis penelitian yang digunakan adalah penelitian deskriptif. Penelitian deskriptif dilakukan untuk mendeskripsikan mengenai persepsi guru dan siswa Jurusan Akuntansi di SMKN 1 Negara. Persepsi guru dan siswa Jurusan Akuntansi di SMKN 1 Negara ditinjau dari dua faktor yaitu factor dari dalam dan faktor dar luar. Adapun populasi yang digunakan dalam penelitian ini yaitu seluruh guru Akuntansi dan siswa Akuntansi di SMKN 1 Negara. Berdasarkan data dari sekolah jumlah guru sebanyak 10 dan jumlah siswa Akuntansi sebanyak 391 orang. Sampel siswa yaitu sebanyak 198 orang dan sampel guru 10 orang.

Tabel 1

Distribusi Sampel dengan Menggunakan Proportional Random Sampling

\begin{tabular}{crr}
\hline Kelas & \multicolumn{1}{c}{$\begin{array}{c}\text { Populasi } \\
\text { (orang) }\end{array}$} & \multicolumn{1}{c}{$\begin{array}{c}\text { Sampel } \\
\text { (orang) }\end{array}$} \\
\hline X & 143 & 72 \\
XI & 106 & 54 \\
XII & 142 & 72 \\
\hline
\end{tabular}

Dalam penelitian ini menggunakan data yang berjenis data kualitatif. Data primer merpakan sumber data yang digunakan dalam penelitian dengan metode pengumpulan data dalam penelitian ini adalah kuesioner. Sebelum digunakan untuk pengumpulan data, maka kuesioner tersebut harus diuji tingkat validitas dan reliabilitasnya. Penelitian ini menggunakan Teknik analisis data deskriptif yang akan mendeskripsikan 
p-ISSN : 2599-1418

e-ISSN : 2599-1426

bagaimana prsepsi guru dan siswa tentang penghapusan ujian nasional. Sebelum melakukan analisi hal yang dilakukan adalah menentukan skor tertinggi dan terendah selanjutnya adalah menentukan interval kelasnya.

\section{Tabel 2}

Skor tertinggi dan terendah persepsi guru dan jurusan siswa Akuntansi di SMKN 1 Negara tentang penghapusan ujian nasional.

\begin{tabular}{clcc}
\hline No. & Dimensi & $\begin{array}{c}\text { Skor } \\
\text { Tertinggi }\end{array}$ & $\begin{array}{c}\text { Skor } \\
\text { Terendah }\end{array}$ \\
\hline 1 & $\begin{array}{l}\text { Faktor } \\
\text { internal } \\
\text { guru }\end{array}$ & 550 & 110 \\
2 & $\begin{array}{l}\text { Faktor } \\
\text { eksternal } \\
\text { guru } \\
3\end{array}$ & 600 & 120 \\
$\begin{array}{l}\text { Faktor } \\
\text { internal } \\
\text { siswa } \\
\text { Faktor } \\
\text { eksternal } \\
\text { siswa }\end{array}$ & 10.890 & 2.178 \\
& 23.880 & 2.376 \\
\hline
\end{tabular}

Tabel 3

Interval untuk Persepsi guru Akuntansi dan siswa Akuntansi di SMKN 1 Negara tentang rencana penghapusan ujian nasional.

\begin{tabular}{clc}
\hline No. & \multicolumn{1}{c}{ Dimensi } & Interval \\
\hline 1 & $\begin{array}{l}\text { Faktor internal } \\
\text { guru }\end{array}$ & 88 \\
2 & $\begin{array}{l}\text { Faktor } \\
\text { eksternal guru }\end{array}$ & 96 \\
3 & $\begin{array}{l}\text { Faktor internal } \\
\text { siswa }\end{array}$ & 1.742 \\
4 & $\begin{array}{l}\text { Faktor } \\
\text { eksternal } \\
\text { siswa } \\
\text { Jumlah }\end{array}$ & 1.900 \\
& 3.477 \\
\hline
\end{tabular}

Tabel 4

Kriteria Total Skor Variabel Persepsi Guru Akuntansi di SMKN 1 Negara Tentang Rencana Penghapusan Ujian Nasional Dilihat Dari Faktor Internal
Jurnal Pendidikan Ekonomi Undiksha

Vol. 13 No. 2 (2021)

\begin{tabular}{ll}
\hline Rentang Skor & \multicolumn{1}{c}{ Kategori } \\
\hline $462-550$ & Sangat Setuju \\
$374-461$ & Setuju \\
$286-373$ & Ragu-ragu \\
$198-284$ & Tidak Setuju \\
$110-197$ & Sangat Tidak \\
& Setuju \\
\hline
\end{tabular}

Tabel 5

Kriteria Total Skor Variabel Persepsi Guru Akuntansi di SMKN 1 Negara Tentang Rencana Penghapusan Ujian Nasional Dilihat Dari Faktor Eksternal

\begin{tabular}{ll}
\hline Rentang Skor & \multicolumn{1}{c}{ Kategori } \\
\hline $504-600$ & Sangat Setuju \\
$408-503$ & Setuju \\
$312-407$ & Ragu-ragu \\
$216-311$ & Tidak Setuju \\
$120-215$ & Sangat Tidak Setuju \\
\hline
\end{tabular}

Tabel 6

Kriteria Total Skor Variabel Persepsi

Siswa Akuntansi di SMKN 1 Negara

Tentang Rencana Penghapusan Ujian

Nasional Dilihat dari Faktor Internal

\begin{tabular}{ll}
\hline Rentang Skor & \multicolumn{1}{c}{ Kategori } \\
\hline $9.148-10.890$ & Sangat Setuju \\
$7.406-9.147$ & Setuju \\
$5.664-7.405$ & Ragu-ragu \\
$3.922-5.663$ & Tidak Setuju \\
$2.180-3.921$ & Sangat Tidak Setuju
\end{tabular}

\section{Tabel 7}

Kriteria Total Skor Variabel Persepsi Siswa Akuntansi Di SMKN 1 Negara Tentang Rencana Penghapusan Ujian Nasional Dilihat Dari Faktor Eksternal 


\begin{tabular}{ll}
\hline Rentang Skor & \multicolumn{1}{c}{ Kategori } \\
\hline $9.980-11.880$ & Sangat Setuju \\
$8.080-9.979$ & Setuju \\
$6.180-8.079$ & Ragu-ragu \\
$4.280-6.179$ & Tidak Setuju \\
$2.380-4.279$ & Sangat Tidak Setuju \\
\hline
\end{tabular}

\section{HASIL DAN PEMBAHASAN}

Persepsi Guru Jurusan Akuntansi di SMKN 1 Negara terhadap penghapusan ujian nasional ditinjau dari faktor internal seperti proses belajar, motivasi, kepribadiannya, menunjukkan hasil seperti pada tabel 8.

Tabel 8

Data Persepsi Guru Jurusan Akuntansi di SMKN 1 Negara Ditinjau dari Dimensi Faktor internal

\begin{tabular}{lccl}
\hline Dimensi & Skor & $\begin{array}{c}\text { Rentang } \\
\text { Skor }\end{array}$ & Kategori \\
\hline Faktor & 398 & $374-461$ & Setuju \\
Internal & & & \\
Total & 398 & $374-461$ & Setuju \\
\hline
\end{tabular}

Berdasarkan hasil analisis pada tabel 8 maka dapat dijelaskan bahwa dimensi faktor internal guru memperoleh skor sebesar 398 yang berada pada rentang skor 374-461, sehingga dapat dikategorikan setuju.

Persepsi Guru Jurusan Akuntansi di SMKN 1 Negara terhadap penghapusan ujian nasionl ditinjau dari faktor eksternal seperti proses intensitas, keberlawanan, pengulangan, ketidak asingan, menunjukkan hasil seperti yang terdapat pada tabel 9.

\section{Tabel 9}

Data Persepsi Guru Jurusan Akuntansi di SMKN 1 Negara Ditinjau dari Dimensi Faktor Eksternal

\begin{tabular}{lccl}
\hline \multicolumn{1}{c}{ Dimensi } & Skor & $\begin{array}{c}\text { Rentang } \\
\text { Skor }\end{array}$ & Kategori \\
\hline $\begin{array}{l}\text { Faktor } \\
\text { Situasional } \\
\text { Total }\end{array}$ & 439 & $408-503$ & Setuju \\
\hline
\end{tabular}

Berdasarkan hasil analisis pada tabel 9 maka dapat dijelaskan bahwa dimensi faktor eksternal guru memperoleh skor sebesar 439 yang berada pada rentang skor 408-503, sehingga dapat dikategorikan setuju.

Persepsi Siswa Jurusan Akuntansi di SMKN 1 Negara terhadap penghapusan ujian nasionl ditinjau dari faktor internal seperti proses belajar, motivasi, kepribadiannya, menunjukkan hasil seperti pada tabel 10.

Tabel 10

Data Persepsi Siswa Jurusan Akuntansi di SMKN 1 Negara Ditinjau dari Dimensi Faktor internal

\begin{tabular}{|c|c|c|c|}
\hline Dimensi & Skor & $\begin{array}{c}\text { Rentang } \\
\text { Skor }\end{array}$ & Kategori \\
\hline $\begin{array}{l}\text { Faktor } \\
\text { Internal }\end{array}$ & 7.814 & $\begin{array}{l}7.406- \\
9.147\end{array}$ & Setuju \\
\hline Total & 7.814 & $\begin{array}{l}7.406- \\
9.147\end{array}$ & Setuju \\
\hline
\end{tabular}

Berdasarkan hasil analisis pada tabel 10 maka dapat dijelaskan bahwa dimensi faktor internal siswa memperoleh skor sebesar 7.814 yang berada pada rentang skor 7.406-9.147, sehingga dapat dikategorikan setuju.

Persepsi Siswa Jurusan Akuntansi di SMKN 1 Negara terhadap penghapusan ujian nasionl ditinjau dari faktor eksternal seperti intensitas, keberlawanan, Pengulangan, ketidak asingan, menunjukkan hasil seperti yang terdapat pada table11.

Tabel11

Data Persepsi Siswa Jurusan Akuntansi di SMKN 1 Negara Ditinjau dari Dimensi Faktor Eksternal

\begin{tabular}{lccl}
\hline Dimensi & Skor & $\begin{array}{c}\text { Rentang } \\
\text { Skor }\end{array}$ & Kategori \\
\hline Faktor & 8.464 & $8.080-$ & Setuju \\
eksternal & & 9.979 & \\
Total & \multirow{2}{*}{8.464} & $8.080-$ & Setuju \\
& & 9.979 & \\
\hline
\end{tabular}

Berdasarkan hasil analisis pada table4 maka dapat dijelaskan bahwa dimensi faktor eksternal siswa memperoleh skor sebesar 8.464 yang 
berada pada rentang skor 8.080-9.979, sehingga dapat dikategorikan setuju.

Secara umum penelitian ini menjelaskan bagaimana persepsi guru dan siswa Jurusan Akuntansi di SMKN 1 Negara terhadap penghapusan ujian nasional. Sebagian besar guru dan siswa setuju dengan beberapa pernyataan yang disajikan oleh peneliti hal ini dapat dilihat pada hasil pembahasan sebelumnya. Berdasarkan apa yang telah dijabarkan di atas, terdapat kesesuaian dengan apa yang dijelaskan oleh Thoha (2015) mengatakan bahwa faktor dari dalam dan faktor dari luar merupakan faktor yang mempengaruhi terjadinya persepsi faktor dari dalam di antaranya proses belajar, kepribadian dan motivasi. Sedangkan faktor dari luar berupa intensitas, keberlawanan pengulangan dan ketidak asingan. Dilihat dari faktor tersebut para guru setuju dengan penghapusan ujian nasional dilihat dari faktor internal dan juga faktor eksternal. Hal ini didukung dengan respon positif guru tentang penghapusan ujian nasioal. Para guru merasa bahwa dengan adanya penghapusan ujian nasional akan menjadikan pedidikan di Indonesia semakin baik kedepannya. Bukan hanya guru saja para siswa juga setuju dengan penghapusan ujian nasional dilihat dari faktor internal dan juga faktor eksternal. Hal ini didukung dengan respon positif siswa tentang penghapusan ujian nasioal. Para siswa merasa dengan adanya penghapusan ujian nasional akan mengurangi beban dan tekanan siswa untuk menghadapi kelulusan dan mereka dapat fokus untuk meningkatkan hasil belajar tanpa adanya tekanan.

\section{SIMPULAN DAN SARAN}

Dilihat berdasarkan dari pembahasan dan analisis data yang telah dijelaskan diatas maka peneliti menarik kesimpulan sebagai berikut. pertamapersepsi guru Jurusan Akuntansi di SMKN 1 Negara Tentang penghapusan ujian nasional ditinjau dari faktor internal dan eksternal memperoleh hasil yang positif. Guru Jurusan Akuntansi di SMKN 1 Negara setuju dengan penghapusan ujian nasional dikarenakan menurut pendapat mereka dengan adanya penghapusan ujian naional akan membuat pendidikan semakin baik. keduapersepsi siswa Jurusan Akuntansi di SMKN 1 Negara Tentang penghapusan ujian nasional ditinjau dari faktor internal dan eksternal memperoleh hasil yang positif. Siswa Jurusan Akuntansi di SMKN 1 Negara setuju dengan penghapusan ujian nasional dikarenakan menurut pendapat mereka dengan adanya penghapusan ujian naional akan membuat pendidikan semakin baik.

Dilihat berdasarkan dari pembahasan dan analisis data yang telah dijelaskan sebelumnya maka terdapat beberapa saran yang dapat diajukan oleh peneliti terhadap beberapa pihak diantaranya. Bagi sekolah disarankan untuk meningkatkan lagi sarana dan prasarana untuk menunjang keberhasilan sistem pendidikan yang baru yaitu berupa penghapusan ujian nasional. Para guru harus selalu update dan memberikan informasi secara cepat dan akurat terhadap siswa terkait dengan dunia pendidikan. Para siswa harus update dalam informasi yang berkaitan dengan dunia Pendidikan baik di dalam sekola hmaupun di luar sekolah. Bagi peneliti lain penelitian ini disarankan lebih dikembangkan lagi, karena di dalam penelitian ini hanya meneliti persepsi guru dan siswa, sehingga untuk peneliti selanjutnya dapat menganalisis dampak penelitian misalnya dengan mengukur seberapa besar dampak penghapusan ujian nasional terhadap perkembangan siswa.

\section{DAFTAR PUSTAKA}

Arikunto, S., \& Jabar. (2004). Evaluasi Program Pendidikan. Bumi Aksara.

Depdiknas. (2003). Undang-undang RI No.20 tahun 2003. tentang sistem pendidikan nasional.

Hartanti, I. S., \& Dwihartani Muslikhah. (2017). Persepsi Siswa dan Guru Terhadap Ujian Nasional Berbasis Komputer (UNBK) di SMK Negeri 1 Godean. Jurnal Pendidikan Administrasi Perkantoran, 7(7), 662672.

Sagala, S. (2009). Konsep Dan Makna Pembelajaran. Alfabeta. 
Simbolan, M. (2008). Persepsi dan

Kepribadian. Jurnal Ekonomi Dan

Bisnis, 2(1), 52-66.

Thoha, M. (2015). Organisasi Konsep dan Dasar Aplikasinya. Raja Grafindo Persada.

Walgito, B. (2010). engantar Psikologi Umum. Andi. 